Prive;Volume 3, Nomor 2, September 2020 http://ejurnal.unim.ac.id/index.php/prive

Online ISSN 2615-7314

Printed ISSN $\underline{2615-7306}$

\title{
FAKTOR-FAKTOR YANG MEMPENGARUHI MAHASISWA AKUNTANSI DALAM MEMILIH KARIR SEBAGAI AKUNTAN PUBLIK PADA MAHASISWA AKUNTANSI PERGURUAN TINGGI DI MOJOKERTO
}

\author{
Tatas Ridho Nugroho, S.Pd., M.Pd ${ }^{1}$ \\ Hari Setiono., SE.,M.Si ${ }^{2}$ \\ Nurul Insanin Arifani ${ }^{3}$ \\ ${ }^{1,2,3}$ Fakultas Ekonomi, Universitas Islam Majapahit
}

\begin{abstract}
The purpose of this study was to determine the factors that influence career selection as a public accountant. Factors that influence the career choice of variables masured by financial reward, professional recognition, work environment, intrinsic value of work, and gender equality. This research uses a quantitative approach with the use of a questionnaire as a data collection tool. The sampling as many as 74 respondents obtained from universities in Mojokerto (UNIM, STIE Al-Anwar). The data analysis undertaken in this study is a classic assumption test, multiple linier analysis, the determination coefficients $\left(R^{2}\right), F$-test, and t-test. The results of this study indicate that the variables of financial rewards, professional recognition, and work environment have a significant influence on career selection as a public accountant. While the intrinsic value of work and gender equality doesn't have a significant influence on career selection as a public accountant.
\end{abstract}

Keywords: financial reward, professional recognition, work environment, intrinsic value of work, gender equality, selection of a career as a public accountant

\begin{abstract}
Abstrak
Tujuan penelitian ini adalah untuk mengetahui faktor-faktor yang mempengaruhi pemilihan karir mahasiswa akuntansi terhadap pemilihan karir sebagai akuntan publik. Faktor-faktor yang mempengaruhi pemilihan karir diukur dengan variabel penghargaan finansial, pengakuan professional, lingkungan kerja, nilai intrinsik pekerjaan, dan kesetaraan gender. Penelitian ini menggunakan pendekatan kuantitatif dengan penggunaan kuesioner sebagai alat pengumpul data. Pengambilan sampel sebanyak 74 responden diperoleh dari universitas di kota Mojokerto (UNIM, STIE-Al-Anwar). Analisis data yang dilakukan dalam penelitian ini adalah uji asumsi klasik, analisis linier berganda, koefisien determinasi $\left(R^{2}\right)$, uji $f$, dan uji t. Hasil dari penelitian ini menunjukkan bahwa variabel penghargaan finansial, pengakuan professional, lingkungan kerja memiliki pengaruh yang signifikan terhadap pemilihan karir sebagai akuntan publik, sedangkan variabel nilai intrinsik pekerjaan dan kesetaraan gender tidak memiliki pengaruh yang signifikan terhadap pemilihan karir sebagai akuntan publik.
\end{abstract}

Kata Kunci: Penghargaan Finansial, Pengakuan Profesional, Lingkungan Kerja, Nilai Intrinsik Pekerjaan, Gender, Pemilihan Karir sebagai Akuntan Publik 


\section{A. PENDAHULUAN}

Pada era yang serba modern seperti sekarang, manusia dituntut untuk mempunyai keahlian supaya bisa mencapai jenjang karir yang diinginkan. Terlebih lagi ada begitu banyak mahasiswa yang di didik untuk menjadi pekerja professional dalam dunia kerja. Maka dari itu, persaingan yang akan dihadapi akan semakin ketat. Dalam menghadapi persaingan, mahasiswa dituntut untuk mulai memikirkan rencana mengenai pemilihan karir apa yang akan dipilihnya nanti. Dalam hal ini bukan hanya mahasiswa semester akhir saja yang harus mulai memikirkan pemilihan karir. Mahasiswa perlu diberi dorongan untuk memilih karir yang sesuai minat dan bakat yang dimiliki.

Akuntansi adalah salah satu jurusan di fakultas ekonomi. Jurusan akuntansi nantinya akan memperoleh profesi yang sangat menjanjikan. Banyak jenjang pemilihan karir yang bisa diambil oleh sarjana Akuntansi, antara lain Akuntan Pendidik, Akuntan Pemerintah, Akuntan Perusahaan dan Akuntan Publik. Akuntan Publik adalah salah satu profesi yang bisa diambil oleh mahasiswa jurusan akuntansi. Akuntan publik berperan sebagai pihak netral yang berada di tengah-tengah hubungan antara pihak internal dan pihak eksternal suatu perusahaan. Netral yang dimaksud disini adalah seorang akuntan publik harus mempunyai sifat independen yaitu tidak berpihak pada pihak internal ataupun pihak eksternal.

Profesi Akuntan Publik memberikan berbagai jenis jasa yang dapat dibagi ke dalam dua kelompok besar, yaitu jasa atestasi dan non atestasi. Pembagian tersebut didasarkan pada perlu tidaknya independensi seorang Akuntan Publik. Jasa atestasi adalah suatu pernyataan pendapat atau perimbangan seseorang yang independen dan kompeten mengenai kesesuaian, dalam segala hal yang signifikan, asersi suatu entitas dengan kriteria yang telah ditetapkan (Rusdiansyah, 2017). Jasa atestasi yang dimaksud dengan audit umum, pemeriksaan (examination), review, dan prosedur yang disepakati (agreed-upon procedures) sedangkan jasa non atestasi adalah jasa yang diberikan oleh akuntan publik yang didalamnya tidak memberikan suatu pendapat, tingkat keyakinan, ringkasan temuan atau bentuk keyakinan lainnya (Rusdiansyah 2017).

Namun pada saat ini profesi Akuntan Publik kurang diminati oleh sebagian besar lulusan akuntansi. Hal ini diungkapkan oleh Dewi Hariyanti dalam Pusat Pembinaan Profesi Akuntansi Kementrian Keuangan News pada 25 Januari 2019. Berdasarkan data dari Pusat Pembinaan Profesi Keuangan (PPPK). Kementrian Keuangan, diketahui bahwa per 21 Januari 2019, jumlah akuntan publik yang aktif sebanyak 1.368 orang publik, $26,1 \%$ di antaranya berumur lebih dari 60 tahun, 25,65 diantaranya berumur 50-59 tahun, 28,8\% berumur $40-45$ tahun, dan sisanya berumur kurang dari 40 tahun. Fakta lain menunjukkan bahwa pertambahan jumlah akuntan publik baru merosot tajam dari 212 izin baru di tahun 2017 menjadi 86 selama tahun 2018. Fakta menunjukkan bahwa profesi akuntan publik tidak menjadi pilihan utama mahasiswa akuntansi untuk berkarir, ditambah lagi tingkat kelulusan ujian Certified Public Accountant (CPA) yang relative rendah, itu pun tidak semua akan terjun ke profesi akuntan publik. antusiasme para pemegang sertifikat CPA untuk memperluas karirnya di kancah ASEAN melalui ASEAN Chartered Professional Accountant (ASEAN CPA) juga tergolong rendah. Data menunjukkan, per 31 Desember 2018, jumlah pemegang ASEAN CPA di Indonesia adalah 559. Jumlah tersebut kalah dengan Malaysia yang sudah membukukan 594 ASEAN CPA, diikuti Thailand dan Singapura dengan 472 dan 386 ASEAN CPA.

Tujuan dalam penelitian ini adalah untuk mengatahui faktor-faktor yang mempengaruhi dipilihnya akuntan publik sebagai karir yang menjanjikan adalah penghargaan financial, pengakuan professional, lingkungan kerja, nilai intrinsik pekerjaan, dan gender. Penghargaan finansial merupakan hasil yang diperoleh dari pekerjaan yang telah dilakukan yang menjadi daya tarik kepuasan karyawan dari sebuah perusahaan. Berdasarkan teori pengharapan, penghargaan finansial merupakan faktor utama dalam pemilihan karir karena pada umumnya seseorang mencari pekerjaan untuk mendapatkan gaji.

Manfaat adanya penelitian ini bagi mahasiswa diharapkan mampu memberikan manfaat bagi universitas guna untuk pertimbangan dalam mendorong minat mahasiswa akuntansi untuk memilih karir sebagai akuntan serta memberi masukan bahwa peluang menjadi akuntan publik sangat besar. 


\section{B. KAJIAN TEORI DAN PENGEMBANGAN HIPOTESIS \\ 1. Teori Pengharapan}

Teori ini sebenarnya telah dikembangkan sejak tahun 1930an. Tetapi model expectancy theory yang sistematis dan komprehensif pertama kali ditemukan oleh Victor Vroom pada bukunya Work and Motivation (1964). Teorinya kemudian dirangkum oleh Edward E. Lawler III dalam Winardi (2001:104) melalui pernyataan berikut:

"....Kekuatan sebuah tendensi untuk bertindak dengan cara tertentu tergantung pada kekuatan sebuah ekspektansi, bahwa tindakan tersebut akan diikuti oleh dampak tertentu atau hasil tertentu dan pada nilai daya tarik konsekuensi bagi pelaku yang bersangkutan (Lawler III, 1973:45)".

Keterkaitan antara teori harapan dengan penelitian ini adalah dalam memilih jalur karir, mahasiswa akuntansi akan ditentukan oleh harapan yang mereka miliki. Apakah karir yang akan mereka pilih dapat memenuhi kebutuhan dan keinginan yang diharapkan contohnya penghargaan finansial/ gaji yang tinggi, lingkungan kerja yang baik, dan pengakuan kemampuan professional yang dimiliki.

\section{Profesi Akuntan Publik}

Profesi akuntan publik menurut Mulyadi (2002:4) profesi akuntan publik merupakan profesi kepercayaan masyarakat, dari profesi inilah masyarakat mengharapkan penilaian yang bebas tidak memihak terhadap informasi yang disajikan oleh manajemen perusahaan dalam laporan keuangan.

\section{Karir di Kantor Akuntan Publik}

Kantor akuntan publik mencerminkan fakta bahwa auditor yang menyatakan pendapat audit atas laporan keuangan harus memiliki lisensi sebagai akuntan publik. KAP seringkali disebut auditor eksternal atau auditor independen untuk membedakannya dengan auditor internal:

Berikut ini adalah gambaran jenjang karir akuntan publik (Mulyadi, 2002):

1. Auditor Junior, bertugas melaksanakan prosedur audit secara rinci, membuat kertas kerja untuk mendokumentasikan pekerjaan audit yang telah dilaksanakan.

2. Auditor Senior, bertugas untuk melaksanakan audit dan bertanggung jawab untuk mengusahakan biaya audit dan waktu audit sesuai dengan rencana, mengarahkan dan mereview pekerjaan auditor junior.

3. Manajer, merupakan pengawas audit yang bertugas membantu auditor senior dalam merencanakan program audit dan waktu audit : mereview kertas kerja, laporan audit dan management letter.

4. Partner, bertanggung jawab atas hubungan dengan klien, dan bertanggung jawab secara keseluruhan mengenai auditing.

\section{Persepsi Mahasiswa Akuntansi Mengenai Profesi Akuntan Publik}

Menurut (Suranto) 2010 persepsi adalah proses internal yang mana telah diakui oleh individu ketika menyeleksi dan mengatur stimuli yang berasal dari luar. Stimuli ini ditangkap oleh indera yang dimiliki seseorang, kemudian secara spontan perasaan dan pikiran individu akan memberikan makna dari stimuliyang ada tersebut. Secara sederhana dapat diartikan jika persepsi adalah proses individu dalam memahami hubungan atau kontak dengan dunia yang ada di sekelilingnya.

\section{Faktor-Faktor yang Mempengaruhi Pemilihan Karir sebagai Akuntan Publik}

Faktor-faktor yang mempengaruhi pemilihan karir sebagai Akuntan Publik, adalah sebagai berikut:

a. Penghargaan Finansial/Gaji

Menurut Warren dkk (2014:546) istilah gaji biasanya mengacu pada pembayaran untuk tenaga kerja bagian manajerial, administrasi, atau jasa kantoran sejenis.

Banyak mahasiswa yang tertarik dengan berkarir di kantor akuntan publik dapat menghasilkan pendapatan yang tinggi dan bervariasi dibandingkan dengan pendapatan yang diperoleh dari karir yang lain, karena semakin besar perusahaan atau klien yang menggunakan jasa akuntan publik, pendapatan yang diterima akan semakin tinggi.

b. Pengakuan Professional 
Pengakuan professional meliputi hal-hal yang berhubungan dengan pengakuan terhadap prestasi. Pengakuan professional ini meliputi adanya kemungkinan bekerja dengan ahli lain, kesempatan untuk berkembang dan pengakuan prestasi (Rahayu et al, 2003 dalam Yantri, 2014). Rahayu (2003) mengungkapkan bahwa mahasiswa yang memiliki profesi akuntan publik dan akuntan perusahaan menganggap bahwa profesi yang mereka pilih akan memberikan banyak kesempatan untuk berkembang.

c. Lingkungan kerja

Menurut Sedarmayanti (2009:21) definisi lingkungan kerja adalah lingkungan keseluruhan alat perkakas dan bahan yang dihadapi, lingkungan sekitarnya dimana seseorang bekerja, metode kerjanya, serta pengaturan kerjanya baik sebagai perseorangan maupun sebagai kelompok.

d. Nilai Intrinsik Pekerjaan

Nilai intrinsik pekerjaan mempengaruhi dalam pemilihan profesi, tetapi terdapat perbedaan pandangan mengenai intrinsic reward dan persepsi mahasiswa terhadap profesi akuntan antara mahasiswa akuntansi yang memilih profesi non akuntan publik (Felton, 1994 dalam Apriliyan, 2011).

e. Kesetaraan Gender

Istilah gender menyangkut perbedaan psikologis, sosial, dan budaya antara laki-laki dan perempuan, sedangkan seks lebih bersifat biologis seperti dijelaskan Gidden dalam (Remiswal, 2013: 12).

Mufidah (2003:3) mendefinisikan gender sebagai perbedaan yang tampak pada laki-laki dan perempuan apabila dilihat dari nilai dan tingkah laku.

\section{METODE PENELITIAN}

\section{Jenis Desain Yang Dipilih}

Jenis desain penelitian yang digunakan dalam penelitian ini adalah metode kuantitatif yang menggunakan analisis data yang berbentuk numerik/angka. Penelitian kuantitatif dapat diartikan sebagai metode penelitian yang berlandaskan pada filsafat posivitism, digunakan untuk meneliti populasi atau sampel tertentu, pengumpulan data menggunakan instrumen penelitian, analisis data bersifat kuantitatif atau statistic dengan tujuan untuk menguji hipotesis (Sugiyono, 2011).

\section{Populasi dan Sampel Penelitian}

\section{a). Populasi}

Populasi yang digunakan dalam penelitian ini adalah mahasiswa jurusan akuntansi semester VI \& VIII angkatan tahun 2015 \& 2016 Fakultas Ekonomi Universitas Islam Majapahit dan mahasiswa jurusan akuntansi semester VI \& VIII angkatan tahun 2015 \& 2016 Fakultas Ekonomi Sekolah Tinggi Ilmu Ekonomi Al-Anwar yang telah menempuh mata kuliah auditing dengan menggunakan teknik pemilihan responden secara acak. Jumlah keseluruhan populasi dalam penelitian ini adalah 274 mahasiswa

\section{b). Sampel}

Sampel dalam penelitian ini ditetapkan untuk mengambil sample diukur dengan menggunakan rumus Slovin yang dikutip dari (Sarjono, 2012).

Formula yang digunakan adalah :

$$
\begin{aligned}
\mathrm{n} & =\frac{N}{N\left(d^{2}\right)+1} \\
\mathrm{n}=\frac{274}{274\left(0,1^{2}\right)+1} & =74(\text { telah dibulatkan }) .
\end{aligned}
$$

\section{Variabel Penelitian}

\section{Variabel Dependen (Terikat)}

Variabel dependen (terikat) merupakan variabel yang dipengaruhi atau yang menjadi akibat karena adanya variabel bebas (Sugiyono, 2012: 4). Dalam penelitian ini yang menjadi variabel dependen adalah pemilihan karir sebagai akuntan publik.

\section{Variabel Independen (Bebas)}

Variabel independen (bebas) merupakan variabel yang mempengaruhi atau yang menjadi perubahan variabel dependen (Sugiyono, 2012:4). Dalam penelitian ini yang merupakan 
variabel independen adalah Penghargaan Finansial (X1), Pengakuan Profesional (X2), Lingkungan Kerja (X3), Nilai Intrinsik Pekerjaan (X4), Kesetaraan Geder (X5).

\section{Teknik Analisis Data}

\section{a. Uji Kualitas Data}

\section{1) Uji Validitas}

Uji validitas digunakan untuk mengukur sah atau valid tidaknya suatu kuesioner, suatu kuesioner dinyatakan valid pertanyaan pada kuesioner mampu untuk mengunkapkan sesuatu yang akan diukur oleh kuesioner tersebut (Ghozali, 2005).

Jika $r$ hitung > $r$ table maka pertanyaan atau indikator tersebut dinyatakan valid, begitu juga sebaliknya jika $r$ hitung $<r$ table maka pertanyaan atau indikator tersebut dinyatakan tidak valid (Ghozali, 2005).

\section{2) Uji Reliabilitas}

Uji reliabilitas merupakan uji yang digunakan untuk mengukur suatu kuesioner yang merupakan indikator dari variabel. Suatu kuesioner dikatakan reliable atau handal jika jawaban seseorang terhadap pernyataan adalah konsisten atau stabil dari waktu ke waktu. Untuk itu mengetahui reliable atau tidaknya suatu variabel dilakukan uji statistik dengan melihat nilai Cronchbach Alpha. Kriteria yang dapat dilakukan adalah sebagai berikut ini: (Ghozali, 2011). Suatu variabel dikatakan reliable jika nilai Cronbach Alpha >0,6.

\section{b. Analisis Statistik Deskriptif}

Statistik Deskriptif dilakukan untuk mengetahui dan memperoleh deskripsi terkait data yang digunakan dalam penelitian dari nilai rata-rata (mean), standar deviasi (deviation standar), varian (variance), nilai minimum, nilai minimum, range, dan sebagainya (Ghozali, 2016).

\section{c. Uji Asumsi Klasik}

Penelitian ini akan diuji menggunakan metode regresi linear berganda untuk mengetahui pengaruh variabel-variabel yang terikat dalam penelitian (Kirana, 2011). Uji penyimpangan asumsi klasik menurut Ghozali (2006) terdiri dari uji multikolinearitas, autokorelasi, heterokedastisitas, dan uji normalitas.

\section{1) Uji Normalitas}

Uji normalitas bertujuan untuk menguji apakah model regresi antara variabel dependen dengan variabel independen mempunyai distribusi normal atau tidak. Dalam uji normalitas ini ada 2 cara untuk mendeteksi apakah residual berdistribusi normal atau tidak, yaitu dengan analisis grafik dan uji statistik (Ghozali, 2006).

Uji normalitas residual dengan metode grafik yaitu dengan melihat penyebaran data pada sumber diagonal pada grafik normal P-P Plot of regression standardized residual. Sebagai dasar pengambilan keputusannya, jika titik-titik menyebar sekitar garis dan mengikuti garis diagonal maka nilai residual tersebut telah normal.

Dalam penelitian ini digunakan Uji One Sample Kolmogrov Smirnov digunakan untuk mengetahui distribusi data, apakah mengikuti distribusi normal, poisson, uniform, atau exponential. Dalam hal ini untuk mengetahui apakah distribusi residual terdistribusi normal atau tidak. Residual berdistribusi normal jika nilai signifikansi lebih dari 0,05.

\section{2) Uji Multikolinearitas}

Uji multikolinearitas bertujuan untuk menguji apakah model regresi ditemukan adanya korelasi antara variabel bebas atau independen (Ghozali, 2006). Multikolinearitas dapat dilihat dengan menganalisis nilai TOL (tolerance) dan nilai VIF (Variance Inflation Factor). Suatu model regresi menunjukkan adanya multikolinearitas jika nilai tolerance > 0,1 , atau nilai VIF $<10$. Model regresi yang baik seharusnya tidak terjadi korelasi antar variabel independen (Ghozali. 2006).

\section{3) Uji Heteroskedastisitas}

Uji Heteroskedastisitas bertujuan menguji apakah dalam model regresi terjadi ketidaksamaan variance dari residual suatu pengamatan ke pengamatan lain (Ghozali, 2011: 139). Untuk mendeteksi ada tidaknya heteroskedastisitas dilakukan pengajuan dengan Uji Glejser. Apabila koefisien signifikansi yang diperoleh lebih besar dari Alpha (sig.>0,05) maka dapat dinyatakan tidak terjadi heteroskedastisitas diantara data. 


\section{d. Analisis Regresi Linear Berganda}

Uji regresi dilakukan untuk mengetahui seberapa besar pengaruh variabel bebas terhadap variabel terikat yaitu antara Penghargaan Finansial (X1), Pengakuan Profesional (X2), Lingkungan Kerja (X3), Kesetaraan Gender (X4), Nilai Intrinsik Pekerjaan (X5), terhadap Pemilihan Karir sebagai Akuntan Publik(Y). Berikut model persamaan regresi yang digunakan :

\section{Keterangan :}

$$
\mathrm{Y}=\mathrm{a}+b_{1} X_{1}+b_{2} X_{2}+b_{3} X_{3}+b_{4} X_{4}+b_{5} X_{5}+\mathrm{e}
$$

Y : Pemilihan Karir Sebagai Akuntan Publik

a : Konstanta

$b_{1} \quad$ : Koefisien regresi penghargaan financial

$b_{2} \quad$ : Koefisien regresi pengakuan profesional

$b_{3} \quad:$ Koefisien regresi lingkungan kerja

$b_{4} \quad$ : Koefisien regresi gender

$b_{5} \quad:$ Koefisien regresi nilai intrinsik pekerjaan

$X_{1} \quad$ : Penghargaan financial

$X_{2} \quad$ : Pengakuan profesional

$X_{3} \quad$ : Lingkungan kerja

$X_{4} \quad$ : Nilai Intrinsik Pekerjaan

$X_{5} \quad:$ Gender

e : Error

\section{e. Pengujian Hipotesis}

\section{1) Pengaruh Simultan (Uji F)}

Menurut Ghozali (2016:96) uji $\mathrm{F}$ bertujuan untuk mengetahui apakah semua variabel independen berpengaruh secara bersama-sama terhadap variabel dependen.

\section{2) Uji Signifikan Parameter Individual (Uji Statistik t)}

Menurut Ghozali (2016:97) uji t bertujuan untuk menunjukkan besar pengaruh variabel independen dalam menerangkan variabel dependen.

\section{3) Koefisien Determinasi $\left(R^{2}\right)$}

Menurut Ghozali (2016:95) koefisien determinasi adalah mengukur seberapa jauh kemampuan model dalam menerangkan variasi variabel dependen.

\section{HASIL DAN PEMBAHASAN}

1. Uji Kualitas Data

a. Uji Validitas

Hasil Pengujian Validitas Variabel Penghargaan Finansial

\begin{tabular}{|c|c|c|c|}
\hline Item Pertanyaan & $r_{\text {hitung }}$ & $r_{\text {table }}$ & Keterangan \\
\hline $\mathrm{X} 1.1$ & 0,720 & 0,361 & Valid \\
\hline $\mathrm{X} 1.2$ & 0,664 & 0,361 & Valid \\
\hline $\mathrm{X} 1.3$ & 0,694 & 0,361 & Valid \\
\hline
\end{tabular}

Hasil Pengujian Validitas Variabel Pengakuan Profesional

\begin{tabular}{lccc} 
Item Pertanyaan & $\boldsymbol{r}_{\text {hitung }}$ & $\boldsymbol{r}_{\text {table }}$ & Keterangan \\
\hline X2.1 & 0,649 & 0,361 & Valid \\
\hline X2.2 & 0,745 & 0,361 & Valid \\
\hline X2.3 & 0,583 & 0,361 & Valid \\
\hline X2.4 & 0,709 & 0,361 & Valid \\
\hline X2.5 & 0,703 & 0,361 & Valid \\
\hline
\end{tabular}

Sumber: Output SPSS Ver. 23.0 yang diolah penulis 
Hasil Pengujian Validitas Variabel Lingkungan Kerja

\begin{tabular}{lccc}
\hline Item Pertanyaan & $\boldsymbol{r}_{\text {hitung }}$ & $\boldsymbol{r}_{\text {table }}$ & Keterangan \\
\hline X3.1 & 0,381 & 0,361 & Valid \\
\hline X3.2 & 0,491 & 0,361 & Valid \\
\hline X3.3 & 0,714 & 0,361 & Valid \\
\hline X3.4 & 0,666 & 0,361 & Valid \\
\hline X3.5 & 0,726 & 0,361 & Valid \\
\hline
\end{tabular}

Sumber: Output SPSS Ver. 23.0 yang diolah penulis

Hasil Pengujian Validitas Variabel Nilai Intrinsik Pekerjaan

\begin{tabular}{lccc}
\hline Item Pertanyaan & $\boldsymbol{r}_{\text {hitung }}$ & $\boldsymbol{r}_{\text {table }}$ & Keterangan \\
\hline X4.1 & 0,481 & 0,361 & Valid \\
\hline X4.2 & 0,705 & 0,361 & Valid \\
\hline X4.3 & 0,649 & 0,361 & Valid \\
\hline X4.4 & 0,451 & 0,361 & Valid \\
\hline X4.5 & 0,461 & 0,361 & Valid \\
\hline
\end{tabular}

Sumber: Output SPSS Ver. 23.0 yang diolah penulis

Hasil Pengujian Variabel Validitas Kesetaraan Gender

\begin{tabular}{lccc}
\hline Item Pertanyaan & $\boldsymbol{r}_{\text {hitung }}$ & $\boldsymbol{r}_{\text {table }}$ & Keterangan \\
\hline X5.1 & 0,437 & 0,361 & Valid \\
\hline X5.2 & 0,467 & 0,361 & Valid \\
\hline X5.3 & 0,530 & 0,361 & Valid \\
\hline X5.4 & 0,686 & 0,361 & Valid \\
\hline X5.5 & 0,407 & 0,361 & Valid \\
\hline
\end{tabular}

Sumber: Output SPSS Ver. 23.0 yang diolah penulis

Hasil Pengujian Validitas Variabel Minat Mahasiswa memilih karir sebagai Akuntan Publik

\begin{tabular}{lccc}
\hline Item Pertanyaan & $\boldsymbol{r}_{\text {hitung }}$ & $\boldsymbol{r}_{\text {table }}$ & Keterangan \\
\hline Y.1 & 0,557 & 0,361 & Valid \\
\hline Y.2 & 0,639 & 0,361 & Valid \\
\hline Y.3 & 0,377 & 0,361 & Valid \\
\hline Y.4 & 0,557 & 0,361 & Valid \\
\hline Y.5 & 0,594 & 0,361 & Valid
\end{tabular}

Sumber: Output SPSS Ver. 23.0 yang diolah penulis

Hasil dari pengujian validitas pada tabel-tabel diatas menunjukkan bahwa masingmasing pertanyaan yang terkait dengan variabel penghargaan finansial, pengakuan professional, lingkungan kerja, nilai intrinsik pekerjaan, kesetaraan gender, dan minat mahasiswa memilih karir sebagai akuntan publik memiliki $r$ hitung lebih besar dari $r$ tabel. Oleh karena itu, seluruh pernyataan dalam kuesioner ini dinyatakan valid.

b. Uji Reliabilitas

\begin{tabular}{lccl}
\hline Variabel & $\begin{array}{l}\text { Cronbach's } \\
\text { Alpha }\end{array}$ & $\begin{array}{l}\text { N of } \\
\text { Items }\end{array}$ & Keterangan \\
\hline Penghargaan Finansial & 0,765 & 3 & Reliabel \\
\hline Pengakuan Profesional & 0,703 & 5 & Reliabel \\
\hline Lingkungan Kerja & 0,757 & 5 & Reliabel \\
\hline
\end{tabular}




\begin{tabular}{llll}
\hline Nilai Intrinsik Pekerjaan & 0,732 & 5 & Reliabel \\
\hline Keseraan Gender & 0,891 & 5 & Reliabel \\
\hline $\begin{array}{l}\text { Minat Mahasiswa memilih karir } \\
\text { sebagai akuntan publik }\end{array}$ & 0,718 & 5 & Reliabel \\
\hline
\end{tabular}

Sumber: Output SPSS Ver. 23.0 yang diolah penulis

Berdasarkan hasil pengujian reliabilitas diatas dapat diketahui hasil Cronbach's Alpha yang menunjukkan nilai diatas 0,60 maka menunjukkan bahwa data keseluruhan reliable

2. Uji Asumsi Klasik

a. Hasil Uji Normalitas

\begin{tabular}{llr}
\hline & & \multicolumn{2}{c}{ Unstandardized } \\
Residual & \\
\hline $\mathrm{N}$ & & 74 \\
\hline Normal Parameters & Mean & .0000000 \\
\hline & Std.Deviation & 2.00285036 \\
\hline Most Extreme & Absolute & .079 \\
\hline Differences & Positive & .079 \\
\cline { 2 - 3 } & Negative & -.052 \\
\hline Test Statistic & & .079 \\
\hline Asymp. Sig. (2-tailed) & .200 \\
\hline Sumber: Output SPSS 23.0 yang diolah penulis
\end{tabular}

Sumber: Output SPSS 23.0 yang diolah penulis

Hasil uji normalitas menggunakan Kolmogrov-Smirnov pada tabel 4.17 Menunjukkan bahwa nilai signifikansi lebih dari 0,05, yaitu 0,200. Maka dari itu, dapat disimpulkan bahwa model regresi memenuhi uji normalitas.

Gambar: Uji Normalitas P-Plot

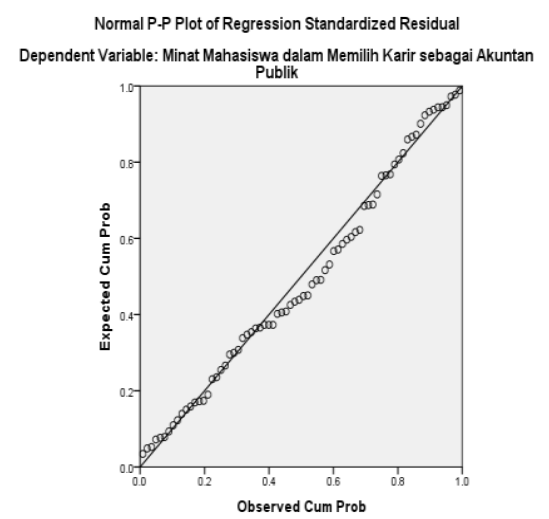

Hasil uji normalitas p-plot menunjukkan bahwa titik-titik menyebar disekitar garis diagonal dan mengikuti arah garis diagonal. Dapat disimpulkan bahwa data berdistribusi normal.

b. Hasil Uji Multikoleniaritas

\begin{tabular}{lcc}
\hline \multirow{2}{*}{ Model } & \multicolumn{2}{c}{ Colinearity Statistics } \\
\cline { 2 - 3 } & Tolerance & VIF \\
\hline (Constant) & & \\
\hline Penghargaan Finansial & .882 & 1.134 \\
\hline
\end{tabular}




\begin{tabular}{lll}
\hline Pengakuan Profesional & .652 & 1.535 \\
\hline Lingkungan Kerja & .719 & 1.390 \\
\hline Nilai Intrinsik Pekerjaan & .690 & 1.449 \\
\hline Kesetaraan Gender & .774 & 1.292 \\
\hline
\end{tabular}

Sumber: Output SPSS 23.0 yang diolah penulis

Hasil uji multikolinearitas pada tabel 4.18 menunjukkan bahwa setiap variabel independen memiliki nilai TOL (tolerance) $>0,1$ dan nilai VIF (Variance Infaltion Factors $)<10$. Maka dari itu, dapat disimpulkan bahwa tidak ada multikolinearitas antara variabel independen.

\section{c. Hasil Uji Heteroskedastisitas}

\begin{tabular}{cccc}
\hline Model & $\begin{array}{l}\text { Unstandardized } \\
\text { Coefficients }\end{array}$ & $\begin{array}{l}\text { Standardized } \\
\text { Coefficients }\end{array}$ & \multicolumn{1}{l}{ Sig } \\
\hline (Constant) & .379 & & .867 \\
\hline X1 & .004 & .005 & .965 \\
\hline X2 & .116 & .227 & .120 \\
\hline X3 & .148 & .206 & .137 \\
\hline X4 & .071 & .125 & .376 \\
\hline X5 & .130 & .229 & .088 \\
\hline
\end{tabular}

Sumber: Output SPSS 23.0 yang diolah penulis

Hasil uji heteroskedastisitas pada tabel 4.19 menunjukkan bahwa sig > 0,05. Maka dari itu, dapat disimpulkan bahwa tidak terjadi masalah heterokedastisitas diantara data penelitian.

\section{Gambar: Uji Heteroskedastisitas Scatterplots}

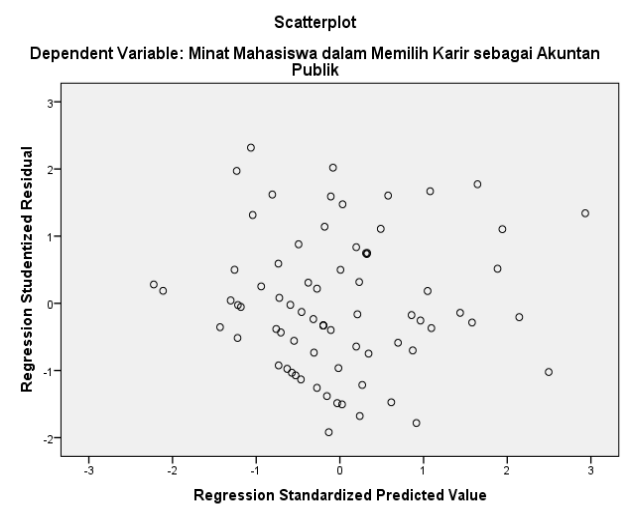

Ada tidaknya hubungan heteroskedastisitas dapat dilihat dari penyebaran data pada grafik scatterplot diatas. Apabila grafik menunjukkan bahwa titik-titik data menyebar diatas dan dibawah atau disekitar angka nol. Titik - titik tidak hanya berkumpul diatas atau dibawah saja. Penyebaran titik-titik data tidak membentuk pola. Dapat disimpulkan bahwa tidak terjadi masalah heteroskedastisitas sehingga model regresi ini layak. 


\section{Hasil Uji Regresi Linear Berganda}

\begin{tabular}{cccccc}
\hline Model & \multicolumn{2}{c}{$\begin{array}{c}\text { Unstandardized } \\
\text { Coefficients }\end{array}$} & \multicolumn{2}{c}{$\begin{array}{c}\text { Standardized } \\
\text { Coefficients }\end{array}$} \\
\hline & B & Std.Error & B & t & Sig \\
\hline (Constant) & 5.319 & 3.985 & & 1.335 & .186 \\
\hline X1 & .361 & .180 & .203 & 2.006 & .049 \\
\hline X2 & .281 & .131 & .253 & 2.145 & .036 \\
\hline X3 & .452 & .174 & .291 & 2.599 & .011 \\
\hline X4 & .183 & .141 & .148 & 1.296 & .199 \\
\hline X5 & .149 & .133 & .121 & 1.119 & .267 \\
\hline
\end{tabular}

Sumber: Output SPSS 23.0 yang diolah penulis

Berdasarkan hasil analisis regresi linier berganda pada tabel 4.19 Diperoleh persamaan regresi linier berganda sebagai berikut.

$\mathrm{Y}=5,319+0,361 \mathrm{X} 1+0,281 \mathrm{X} 2+0,452 \mathrm{X} 3+0,183 \mathrm{X} 4+0,149 \mathrm{X} 5$

Pada tabel diatas diketahui nilai konstanta sebesar 5,319. Hal ini dapat diartikan bahwa variabel independen penghargaan finansial, pengakuan professional, lingkungan kerja, dan nilai intrinsik pekerjaan sama dengan 0, maka variabel dependen yaitu minat mahasiswa memilih karir sebagai akuntan publik, bernilai positif sebesar 5,319.

\section{Uji Hipotesis}

a. Hasil Uji Signifikansi Simultan (Uji F)

\begin{tabular}{|c|c|c|c|c|c|c|}
\hline \multicolumn{2}{|c|}{ Model } & $\begin{array}{c}\text { Sum of } \\
\text { Squares }\end{array}$ & df & $\begin{array}{c}\text { Mean } \\
\text { Square }\end{array}$ & $\mathbf{F}$ & Sig. \\
\hline \multirow{3}{*}{ I } & \multirow{3}{*}{$\begin{array}{l}\text { Regression } \\
\text { Residual } \\
\text { Total }\end{array}$} & 184.154 & 5 & 36.831 & 8.553 & .000 \\
\hline & & 292.833 & 68 & 4.306 & & \\
\hline & & 476.986 & 73 & & & \\
\hline
\end{tabular}

Sumber: Output SPSS 23.0 yang diolah penulis

Berdasarkan tabel 4.21 hasil uji $\mathrm{F}$ menunjukkan nilai signifikansi yang diperoleh adalah sebesar $0,000<0,05$. Maka dari itu dapat disimpulkan bahwa variabel penghargaan finansial, pengakuan professional, lingkungan kerja, nilai intrinsik pekerjaan, dan kesetaraan gender secara simultan berpengaruh terhadap minat mahasiswa dalam memilih karir sebagai akuntan publik.

b. Hasil Uji Hipotesis Parsial

\begin{tabular}{lcc}
\hline Model & t & Sig. \\
\hline 1 (Constant) & 1.335 & .186 \\
\hline Penghargaan Finansial & 2.006 & .049 \\
\hline Pengakuan Profesional & 2.145 & .036 \\
\hline Lingkungan Kerja & 2.599 & .011 \\
\hline Nilai Intrinsik Pekerjaan & 1.296 & .199 \\
\hline Kesetaraan Gender & 1.119 & .267 \\
\hline
\end{tabular}

Sumber: Output SPSS 23.0 yang diolah penulis 
Jika sig. $<0,05$, maka H0 akan ditolak, begitupun sebaliknya. Berdasarkan tabel 4.22 hasil dari uji parsial (t-test) adalah sebagai berikut:

1) Berdasarkan hasil uji t pada model regresi, diperoleh nilai signifikansi variabel penghargaan finansial sebesar 0,049 < 0,05 sehingga H0 ditolak. Maka dari itu, dapat disimpulkan bahwa variabel penghargaan finansial berpengaruh positif terhadap minat mahasiswa memilih karir sebagai akuntan publik.

Hasil penelitian yang menunjukkan bahwa penghargaan finansial berpengaruh positif terhadap minat mahasiswa dalam memilih karir sebagai akuntan publik telah mendukung teori pengharapan. Dalam teori pengharapan, motivasi individu ditentukan oleh keyakinan tentang kemungkinan bahwa perilaku tertentu (misalnya bekerja keras) akan menimbulkan hasil tertentu (misalnya kenaikan gaji dan juga bonus).

2) Berdasarkan hasil uji t pada model regresi, diperoleh nilai signifikansi variabel pengakuan profesional sebesar 0,036 $<0,05$ sehingga H0 ditolak. Maka dari itu, dapat disimpulkan bahwa variabel pengakuan profesional berpengaruh positif terhadap minat mahasiswa memilih karir sebagai akuntan publik.

Hasil penelitian yang menunjukkan bahwa pengakuan professional berpengaruh positif terhadap minat mahasiswa dalam memilih karir sebagai akuntan publik telah mendukung teori pengharapan. Pada penelitian ini, responden beranggapan pengakuan professional yang diperoleh dari pekerjaan sebagai akuntan publik tersebut dianggap dapat memberikan rasa bangga akan prestasi yang telah dicapai. Pengakuan professional ini meliputi adanya kemungkinan bekerja dengan ahli yang lain, dan kesempatan untuk berkembang.

3) Berdasarkan hasil uji t pada model regresi, diperoleh nilai signifikansi variabel lingkungan kerja sebesar 0,011 $<0,05$ sehingga H0 ditolak. Maka dari itu, dapat disimpulkan bahwa variabel lingkungan kerja berpengaruh positif terhadap minat mahasiswa memilih karir sebagai akuntan publik.

Hasil penelitian yang menunjukkan bahwa lingkungan kerja berpengaruh positif terhadap minat mahasiswa dalam memilih karir sebagai akuntan publik telah mendukung teori pengharapan. Pada penelitian ini, responden beranggapan lingkungan kerja yang memiliki tekanan kerja dan kompetisi yang tinggi akan memberikan tantangan tersendiri bagi individu yang menyukai tantangan.

4) Berdasarkan hasil uji t pada model regresi, diperoleh nilai signifikansi variabel nilai intrinsik pekerjaan sebesar 0,199 <0,05 sehingga H0 diterima. Maka dari itu, dapat disimpulkan bahwa variabel nilai intrinsik pekerjaan tidak berpengaruh terhadap minat mahasiswa memilih karir sebagai akuntan publik.

Dalam penelitian ini, minat mahasiswa untuk memilih karir sebagai akuntan publik diukur dengan indikator berupa menantang intelektual, memerlukan keterampilan. Dalam variabel nilai intrinsik pekerjaan indikator tersebut tidak mempengaruhi. Jadi walaupun profesi akuntan publik adalah profesi yang menantang intelektual dan termasuk pekerjaan yang sulit dalam menyelesaikannya. Hal tersebut tidak mempengaruhi minat mahasiswa.

5) Berdasarkan hasil uji t pada model regresi, diperoleh nilai signifikansi variabel kesetaraan gender sebesar 0,267 <0,05 sehingga H0 diterima. Maka dari itu, dapat disimpulkan bahwa variabel kesetaraan gender tidak berpengaruh terhadap minat mahasiswa memilih karir sebagai akuntan publik.

Dalam penelitian ini, minat mahasiswa untuk memilih karir sebagai akuntan publik diukur dengan indikator berupa hak pria dan wanita berbeda dan ruang lingkup terbatas. Dalam variabel kesetaraan gender indikator tersebut tidak mempengaruhi. Jadi walaupun ada hak dan kewajiban pria dan wanita dalam dunia kerja akuntan publik berbeda. Hal tersebut tidak mempengaruhi minat mahasiswa. Selain itu ruang lingkup pekerjaan wanita terbatas diartikan bahwa wanita harus punya waktu untuk mengurus keluarga, sedangkan profesi akuntan publik merupakan profesi yang sangat menyita waktu.

c. Hasil Uji Koefisien Determinasi

\begin{tabular}{lllll}
\hline Model & R & R & Adjusted & Std. Error of \\
\hline
\end{tabular}




\begin{tabular}{|c|c|c|c|c|}
\hline & & Square & R Square & the Estimate \\
\hline 1 & $.621^{\mathrm{a}}$ & .386 & .341 & 2.07518 \\
\hline
\end{tabular}

Berdasarkan hasil uji koefisien determinasi pada tabel 4.22 diperoleh nilai $\mathrm{R}$ square sebesar 0,386. Hal tersebut menunjukkan bahwa variabel penghargaan finansial, pengakuan professional, lingkungan kerja, nilai intrinsik pekerjaan, dan kesetaraan gender secara keseluruhan memiliki pengaruh terhadap minat mahasiswa dalam memilih karir sebagai akuntan publik sebesar 38\%\%, sedangkan sisanya sebesar $62 \%$ dipengaruhi oleh hal lain diluar penelitian ini.

\section{SIMPULAN DAN SARAN}

1. Penghargaan Finansial berpengaruh positif terhadap minat mahasiswa dalam memilih karir sebagai akuntan publik. hal ini dikarenakan oleh tujuan awal seseorang bekerja adalah untuk mendapatkan penghargaan finansial berupa gaji untuk memenuhi kebutuhan hidup. Sehingga apabila penghargaan finansial profesi akuntan tinggi, maka akan meningkatkan motivasi mahasiswa untuk memilih karir sebagai akuntan publik.

2. Pengakuan professional berpengaruh positif terhadap minat mahasiswa dalam memilih profesi sebagai akuntan publik. hal ini dikarenakan pada dasarnya manusia membutuhkan pengakuan dari orang lain atas perolehan atau prestasi yang dicapai. Sehingga pengakuan professional akan meningkatkan minat mahasiswa memilih profesi sebagai akuntan publik.

3. Lingkungan kerja berpengaruh positif terhadap minat mahasiswa dalam memilih karir sebagai akuntan publik. hal ini dikarenakan lingkungan kerja yang baik akan mempengaruhi kinerja seseorang dalam menyelesaikan pekerjaannya dan lingkungan kerja yang kondusif akan membentuk karakter seorang karyawan. Sehingga lingkungan kerja yang baik akan meningkatkan motivasi mahasiswa untuk memilih karir sebagai akuntan publik.

4. Nilai intrinsik pekerjaan tidak berpengaruh terhadap minat mahasiswa memilih karir sebagai akuntan publik. hal ini disebabkan karena sebagian mahasiswa kurang memiliki ambisi untuk berkembang, kurang menyenangi tantangan, kurang memahami dan mengerti tentang standar auditing dan standar akuntansi, dan kurang banyak membaca agar dapat mengetahui perkembangan terbaru tentang dunia akuntan publik.

5. Kesetaraan gender tidak berpengaruh terhadap minat mahasiswa dalam memilih karir sebagai akuntan publik hal ini karena kodrat wanita adalah mengurus rumah tangga sedangkan kalau bekerja menjadi akuntan publik yang sangat menyita waktu menjadikan wanita tidak mengurus rumah tangga.

\section{DAFTAR RUJUKAN}

Aprilyan, Lara Absara.2011. Faktor-Faktor yang Mempengaruhi Mahasiswa Akuntansi Dalam Pemilihan Karir Menjadi Akuntan Publik. Skripsi. Semarang. Universitas Diponegoro. Http://eprints.undip.ac.id/26837/

Dewayani, Mega Arista, dkk. 2017. Faktor-Faktor yang Memengaruhi Mahasiswa Akuntansi dalam Pemilihan Karir sebagai Akuntan Publik. Universitas Muhammadiyah Magelang. The 6th University Research Colloquium 2017. ISSN 2407-9189. http://journal.ummgl.ac.id/index.php/urecol/article/view/740

Ghozali, Imam. 2016. Aplikasi Analisis Multivariate dengan IBM SPSS 23. Edisi 8. Semarang: UNDIP

Mufidah. 2003. Paradigma Gender. Malang: Bayumedia Publishing. 
Mulyadi. 2001. Sistem Akuntansi. Jakarta: Salemba Empat.

Mulyadi. 2002. Auditing (buku 2). Jakarta: Saalemba Empat.

Rahayu, Sri dkk. 2003. Persepsi Mahasiswa Akuntansi di Berbagai Universitas Negeri dan Universitas Swasta yang ada di Wilayah Jakarta, Yogyakarta, dan Surakarta, Mengenai Faktor-Faktor yang Mempengaruhi Pemilihan Karir sebagai Akuntan Publik, Akuntan Perusahaan, Akuntan Pendidik, dan Akuntan Pemerintah. Simposium Nasional Akuntansi VI, Surabaya, 16-17 Oktober.

Rusdiansyah, Yunifan. 2017. Faktor-Faktor yang Mempengaruhi Pemilihan Karir Menjadi Akuntan Publik. Padang: Simposium Nasional Akuntansi IX. ISSN: 2460-0585 Jurnal Ilmu dan Riset Akuntansi Vol 6 No 9, September 2017. http://eprints.ums.ac.id/66791/

Remiswal. 2013. Menggugah Partisipasi Gender di Lingkungan Komunitas Lokal. Yogyakarta: Graha Ilmu.

Soedarmayanti. 2009. Suatu Tujuan dari Aspek Ergonomi atau Kaitan antara Manusia dengan Lingkungan Kerjanya. Bandung: CV Mandar Maju.

Sugiyono. 2012. Statistika untuk Penelitian. Bandung: Alfabeta.

Sugiyono. 2015. Metode Penelitian Kuantitatif R\&D. Bandung: Alfabeta

Suranto, A. W. 2010. Komunikasi Sosial Budaya. Yogyakarta: Graha Ilmu.

Warren C.S., J.M. Reeve, J.E. Duchac, N. Suhardianto, D.S. Kalajanti, A.A. Jusuf, dan C.D Djakaman. 2014. Pengantar Akuntansi (Adaptasi Indonesia). Edisi Kedua Puluh Lima. Jakarta: Salemba Empat.

Winardi, 2001. Motivasi dan Permotivasian Dalam Manajemen. Jakarta: PT. Rajagrafindo Persada.

Zaid, Muhammad Ikhwan, 2015. Pengaruh Gender, Penghargaan Finansial, dan Pertimbangan Pasar Kerja Terhadap Minat Mahasiswa Akuntansi untuk Berkarir Menjadi Akuntan Publik (Studi Kasus pada Mahasiswa Akuntansi Universitas Negeri Yogyakarta). SKRIPSI. Universitas Negeri Yogyakarta. http://journal.student.uny.ac.id/ojs/ojs/index.php/profita/article/view/5997

Http://pppk.kemenkeu.go.id/News/Details/2142 diakses tanggal 21 Februari 2019. Pukul 21.18 WIB. 